\title{
DIE WÊRELDBEELD VAN DIE GEREFORMEERDE BIOLOOG, JAN LEVER (1922-2010): VAN EVOLUSIETEORIE NA 'N EVOLUSIONISTIESE GELOOF?
}

Author:

Barend J van der Walt ${ }^{1}$

\section{Affiliation: \\ ${ }^{1}$ Skool vir Filosofie Potchefstroomkampus Noordwes-Universiteit, Potchefstroom}

\section{Correspondence to:} Barend J van der Walt

\section{Postal Address:}

Private Bag X6001,

Potchefstroom Campus, North-West University, Potchefstroom, 2520, South Africa

Email:

benniejvanderwalt@gmail.com

Dates:

15 August 2016

\section{How to cite this article:} van der Walt, B.J., 2016. "DIE WÊRELDBEELD VAN DIE GEREFORMEERDE BIOLOOG, JAN LEVER (1922-2010): VAN EVOLUSIETEORIE NA ' $N$ EVOLUSIONISTIESE GELOOF?". KOERS - Bulletin for Christian Scholarship, 81(1). Available at: http://dx.doi.org/10.19108/ KOERS.81.1.2253

\section{Copyright:}

(c) 2015. The Author(s). Published under the Creative Commons Atribution License.

\author{
The world-picture of the reformed biologist, Jan Lever (1922-2010): from an evolutionary \\ theory towards an evolutionistic faith?
}

\begin{abstract}
Evolution as a theory is today proclaimed widely, accepted by many as a fact and is often reflected even in South Africa in prescribed textbooks for schools and universities. The main question to be discussed in this reflection is whether the idea of evolution always remains a mere theory. Does it not often, even unintentionally, eventually develop into an evolutionistic faith or worldview and thus would become to Christians an unacceptable worldview? Different contemporary secular thinkers openly acknowledge the dependence of their theory of evolution upon an agnostic or an atheistic faith and/or, vice versa, their evolutionary theory leading toward unbelief.
\end{abstract}

Some Christian-reformed natural scientists (1) clearly rejected the hypothesis of evolution, including an evolutionistic worldview. Others (2), again including those from the reformed Christian tradition, are of the opinion that, after God (before time) created everything, reality unfolded or developed under His guidance. In the case of a third group of (3) Christian evolutionary scientists it seems as if the compromise or synthesis which they tried to achieve between their Christian convictions and their scientific hypotheses could not be achieved. Finally they had to choose in favour of the one or the other.

A first article (cf. Van der Walt, 2016a) already discussed these varying and even clashing viewpoints among Christians. It focussed on the position of an earlier, well-known reformed theologian from the Netherlands (Abraham Kuyper) and a South African Christian philosopher (Hendrik Stoker). A second contribution on the same issue (cf. Van der Walt, 2016b) shifted attention to the viewpoints of three biologists from the reformed Christian circle, viz. Harry Diemer, Duyvené de Wit and Jan Lever. The first two of them may be regarded as representatives of position (2) above, while the third initially belonged to (2) but after about 1970 gradually developed towards (3).

The present article follows Lever's thinking from about the seventies up to 2010. An increasing tension developed between his Christian belief in the Bible, and God as Creator and his zoological research according to an evolutionary paradigm. It gradually becomes evident that he ascribed such weight and even revelationary power to his scholarly results that it eventually clashed and overpowered his Christian worldview, replacing it with an evolutionistic world-picture or even a (semi-)evolutionistic worldview.

Evolusie as teorie word vandag wyd verkondig, deur baie as 'n feit aanvaar, en word dus ook gereflekteer in handboeke vir sekondêre en tersiêre instellings. Die hoofprobleem wat in hierdie refleksie bespreek word, is of die evolusieteorie altyd 'n blote teorie of hipotese bly. Gebeur dit nie dikwels, selfs onbedoeld en geleidelik, dat dit eventueel in 'n evolusionistiese geloof en lewensvisie ontwikkel en op dié wyse vir Christene ' $n$ onaanvaarbare wêreldbeskouing word nie? Verskillende huidige sekulêre denkers erken vandag reeds openlik die afhanklikheid van hulle evolusieteorie van'n agnostiese of ateïstiese geloof en/of die omgekeerde: dat hulle evolusieteorie tot so'n geloof voer.

Sommige Christelike natuurwetenskaplikes (1) verwerp duidelik die evolusieteorie en ook 'n evolusionistiese lewensvisie. Ander (2), wat ook verteenwoordigers uit die Christelikgereformeerde tradisie insluit, is van mening dat, nadat God (voor tyd daar was) alles geskep het, die werklikheid onder sy voorsienigheid verder ontplooi of evolveer het. In die geval van 'n derde groep Christelik-evolusionêre bioloë (3) wil dit voorkom asof die kompromie of sintese 
wat hulle tussen hulle Christelike oortuigings en wetenskaplike hipoteses en teorieë wou bereik, gefaal het. Aan die einde moes hulle vir die een of die ander kies.

In 'n eerste artikel (vgl. Van der Walt, 2016a) is alreeds hierdie verskillende en selfs botsende gesigspunte onder Christenwetenskaplikes bespreek. Dit was toegespits op die standpunte van 'n vroeëre bekende gereformeerde teoloog (Abraham Kuyper) van Nederland en 'n Suid-Afrikaanse Christelike filosoof (Hendrik Stoker). In 'n tweede bydrae oor dieselfde vraagstuk het die aandag geval op die visies van drie gereformeerde bioloë, naamlik Harry Diemer, Duyvené de Wit en Jan Lever (vgl. Van der Walt, 2016b). Die eerste twee kan beskou word as verteenwoordigers van standpunt (2) hierbo, terwyl die derde persoon se siening aanvanklik ook onder dieselfde groep geval het, maar sedert ongeveer 1970 in die rigting van (3) ontwikkel het.

Die huidige artikel volg Lever se ontwikkeling vanaf ongeveer 1970 tot 2010. Daarvolgens ontstaan daar 'n toenemende spanning tussen sy Christelike geloof in die Bybel van God as Skepper en sy dierkundige navorsing volgens 'n evolusionêre paradigma. Dit word duidelik dat hy geleidelik soveel gewig en selfs openbarende krag aan sy wetenskaplike resultate geheg het dat dit eventueel gebots het met en selfs sy Christelike lewensbeskouing oorrompel het om vervang te word met 'n evolusionistiese wêreldbeeld of selfs (semi-) evolusionistiese wêreldvisie.

\section{INLEIDEND}

\section{1 'n Kort lewensgeskiedenis}

Volgens die Christelike Encyclopedie (2012) het Lever in 'n Gereformeerde huis grootgeword waar daar volgens die gereformeerde Ou-Testamentikus, Aalders (1932) geglo is dat God stof, plant, dier en mens net ongeveer 15,000 jaar gelede volledig in ses dae geskape het. Lever sou gedurende sy lewe hierdie gedagte omverwerp. Alreeds as kind het hy as (toekomstige) bioloog ontpop deur miere, ruspes, spinnekoppe, slakke, 'n skilpad, kat en bok as troeteldiere aan te hou.

In sy skoolbiblioteek vind hy die in Nederlands vertaalde boek van 'n Duitse evolusionis, Wilhelm Bölsche met die titel Afstamming van den mensch, wat die skepping in ses dae en die paradystoerstand afwys. Later lees hy as skoolkind ook nog die werk De wetenschap van het leven van twee Britse evolusionistiese bioloë, J. Huxley en H.G. Wells.

Toe (aldus Lever, later) wou hy egter ook weet wat sy medegereformeerde denkers oor evolusie en evolusionisme geskryf het. Met eie sakgeld koop hy (antikwaries) die toespraak van die bekende gereformeerde teoloog, Abraham Kuyper (1899) en skryf later dat hy in dieselfde lyn as Kuyper gedink het, naamlik kreatiewe evolusie (vgl. Van der Walt, 2016a).

Hy is ook beïnvloed deur die geskrifte van die Groningse bioloog, J.H. Diemer (1904-1945) wat (teenoor die Christelike supra-naturaliste) geleer het dat wonders nie 'n bonatuurlike ingrype van God in die gang van die natuur beteken nie, maar dat hulle as iets natuurliks beskou moet word (vgl. Diemer, 1963 of 1977).

Lever promoveer in 1950 in Dierkunde met' $n$ proefskrif oor die struktuur van die skildklier, word in dieselfde jaar as dosent in soölogie aan die pas-gestigte mediese fakulteit van die Vrije Universiteit aangestel en in 1952 tot professor bevorder waar hy tot by sy aftrede in 1986 doseer.

\subsection{Nagelate geskrifte}

Van Woudenberg het die leser'n guns bewys deur as redakteur op te tree vir'n versamelwerk met 'n keur uit Lever se oeuvre oor vyftig jaar tot by 2005 onder die titel Langs de mysterieuze grenzen van het leven (Lever, 2006a). Dit bied ' $n$ goeie beeld van Lever se ontwikkeling oor'n lang tydperk. Let egter op die voetnote by elke hoofstuk - hulle is ongelukkig nie kronologies gerangskik nie.

In sy inleiding skep Van Woudenberg (Lever, 2006a:10 e.v.) ook die indruk dat Lever dwarsdeur sy loopbaan dieselfde standpunt gehuldig het. My noukeurige lees van Lever se geskrifte toon egter 'n geleidelike verskuiwing vanaf veral die sewentigerjare. Hierdie wysiging van Lever se standpunt sal hieronder duidelik aangetoon word.

\subsection{Opset}

Daar word dus, in opvolging van wat reeds oor Lever se standpunt tot 1969 geskryf is (vgl. Van der Walt, 2016b), verder nagegaan hoe Lever sy versoening tussen sy evolusieteorie en sy Christelike geloof regverdig het. Agtereenvolgens word die volgende bekyk: (1) Lever se onderskeid tussen die Bybelse openbaring dat God geskep het en hoe die skepping daarna evolusionêr ontwikkel het. (2) Die vraag word gestel of laasgenoemde proses outonoom verloop; (3) of Lever se oplossing nie op 'n nuwe soort natuurlike teologie neerkom nie; (4) of die skeidslyn tussen evolusieteorie en evolusionisme nie vervaag nie. (5) Laastens hoe hy as bioloog die Bybel lees en wat die implikasies is wat dit vir sy Christelike geloof inhou. Ten slotte word gelet op die reaksie wat die Christelike filosoof, K.J. Popma, reeds in 1969 op Lever se beskouinge gelewer het. Daarin is ook alreeds sommige van Lever se latere ontwikkelinge voorsien.

\section{DIE ONDERSKEID TUSSEN “DAT" EN "HOE"}

Lever (1956:68) tref alreeds vroeg in sy loopbaan die onderskeid tussen dat God geskep het en hoe dit sou gebeur het. Dan sê hy egter nog dat die hoe'n misterie is:

"Wij houden... vast, hoe onwetenschappelijk het buitenstaanders in de oren moge klinken, dat God deze mens heefte geschapen, hoe dan ook" (kursivering bygevoeg). 


\subsection{Kommentaar}

Later word die hoe-vraag egter deur sy evolusieteorie beantwoord. Die vraag is of dit nie 'n kunsmatige skeiding beteken nie. Impliseer die dat nie ook 'n hoe nie en die omgekeerde?

Maar nog meer probleme duik op. Impliseer die hoe-antwoord'n neutrale biologie? Oorskry die hoe-antwoord nie die grense wat Lever vroeër self aan die wetenskap gestel het nie, naamlik dat dit nie die ontstaan van maar alleen die bestaande werklikheid kan bestudeer?

Indien ' $\mathrm{n}$ mens sou onderskei tussen die dat van God se openbaring (dat hy Skepper van alles is) en die hoe van die wetenskap, impliseer dit nie dat God se Skrifopenbaring aangevul moet word nie, omdat dit onvolledig of selfs gebrekkig sou wees? Hoe Hy geskep het, moet die evolusionêre biologie dus vir ons sê.

Die vraag is selfs of die hoe by Lever net op'n neutrale aanvulling neergekom het. Lei so 'n onderskeid nie uiteindelik tot die korreksie en selfs die oorwoekering en vervanging van God se openbaring nie? Nie 'n versoening tussen Skrifgeloof en die evolusieteorie is dan die resultaat nie, maar die opoffering van eersgenoemde aan laasgenoemde.

\subsection{Het die (biologiese) wetenskap oorwin?}

Ongelukkig het Lever se wetenskaplike oortuigings (die hoe van sy evolusionêre wêreldbeeld) blykbaar oor sy geloof (die dat van sy Christelike wêreldvisie) getriomfeer. In plaas daarvan dat sy lewensvisie sy wetenskap gelei het, het die wetenskap sy Christelike visie begin ondergrawe.

In plaas van dat hy sy biologie in die lig van God se openbaring beoefen het, het die omgekeerde gebeur. Aan sy wetenskap is heelwaarskynlik'n openbaringskarakter toegeken.

Dat sintesedenke nooit kan slaag nie, word hier duidelik. Uiteindelik moes Lever kies tussen God se openbaring en die "openbaring" van sy wetenskaplike werk. Dan word dit'n keuse tussen twee lewensbeskouings.

\section{IS EVOLUSIE 'n OUTONOME PROSES?}

In Lever (1957a, 1957b, 1957c, 1958a en 1958b) maak hy nog 'n duidelike onderskeid tussen evolusieteorie, evolusionisme en sy skeppingsgeloof. Maar net' $n$ dekade later (vgl. Lever, 1969 en 1970) kry'n mens alreeds die indruk dat God blykbaar slegs die evolusieproses aan die gang gesit het, maar nie verder daarby betrokke sou wees nie - dit voltrek sigself heeltemal selfstandig volgens genetiese veranderings, natuurlike seleksie en so meer. Dit wil dus lyk of Lever se skeppingsgeloof en sy wetenskap nie meer so nou saamgaan nie. Sy geloof word al dunner.

Verder glo Lever ook nie meer (heelwaarskynlik onder die invloed van die sogenaamde "nuwe teologie" van onder andere Kuitert) in die letterlike betekenis van die Bybel nie. Adam en Eva is vir hom nie meer historiese figure nie, maar word vervang met die mitiese figuur van Elkerlijk, wat slegs 'n simbool van die lewe van elke mens sou wees (vgl. Lever, 1973:28,45,51). Fundamentele Skrifwaarhede, soos die sondeval, word alreeds afgewater.

Opmerklik is verder dat Lever later (in 1986, opgeneem in Lever, 2006a:199-216) groot waarde aan toevalligheid begin heg 'n tipiese trek van die evolusionisme.

\section{4. 'n HEDENDAAGSE VORM VAN NATUURLIKE TEOLOGIE IN PLAAS VAN'n INTEGRALE CHRISTELIKE WETENSKAP?}

'n Verdere resultaat van die geleidelike verskuiwing in Lever se denke is dat hy al minder nadruk plaas op God se openbaring in die skepping en al meer op die mens se ervaring van en verbasing oor hoe wonderlik die natuur is.

\subsection{Subjektiewe, eie belewenis}

Dit blyk byvoorbeeld duidelik uit Lever (2005:78) waar hy besondere klem op hierdie emosionele belewenis lê, dus al meer subjektivisties word en afsluit dat 'n mens agter die sienlike die Onsienlike van'n heeltemal ander wêreld vermoed, ja, selfs daarin kan glo.

Dieselfde gedagte vind ons later ook in hoofstuk 20 van Lever se laaste werk (2010:255-260) met die titel "Het geloof in de Schepper houdt stand". Die mens se belewinge van die natuur laat jou verstand tot belangrike vermoedens kom: Dit laat 'n mens 'n skepper of die Skepper vermoed. Indien wel, lei dit tot teïsme. Indien nie, impliseer dit gewoonlik ateïsme of agnostisisme (in Lever se geval seker'n soort teïsme).

\section{2 'n Natuurlik-bonatuurlike dualisme?}

'n Mens kan nie aan die indruk ontkom nie dat Lever, ten spyte daarvan dat hy aanvanklik die supranaturalisme bestry het, in 'n vorm van natuurlik-bonatuurlike dualisme verval. Dit blyk daaruit dat hy - al is dit hoe versigtig - vanuit sy eie natuurbelewing die bestaan van'n skepper vermoed.

Dit kom myns insiens neer op'n moderne variant van die oeroue natuurlike teologie. Die verskil tussen die ouere pogings en dié van Lever is die volgende. In Griekse denke (bv. Aristoteles) en later in die Middeleeue (bv. Thomas van Aquino) is gepoog om vanuit die menslike rede die bestaan van God te bewys. In die geval van Lever word vanuit sy ervaring van die wonderlike natuur slegs die bestaan van'n Onsienlike vermoed. In die lig van die titel van Lever se artikel van 1996 (vgl. Lever, 2005), lyk dit ook na'n negatiewe soort natuurlike teologie, omdat die natuur alleen tot die onsienlike lei en nie positief kan verklaar wie of wat die onsienlike werklik sou wees nie.

God laat egter nie sy bestaan (of nie-bestaan) afhanklik maak daarvan of ' $n$ nietige mens sy bestaan kan bewys, aantoon of selfs net vermoed nie. Selfs so 'n afgewaterde natuurlike teologie, soos dié van Lever, beteken in alle geval nog glad nie 'n integrale Christelike wetenskap nie. 


\section{DIE SKEIDSLYN TUSSEN EVOLUSIETEORIE EN EVOLUSIONISME VERVAAG}

Teoreties kan (soos Lever ook aanvanklik gedoen het) onderskei word tussen evolusieteorie en evolusionisme. Volgens Klapwijk (2009:52,53) bestaan daar in werklikheid egter nie so 'n duidelike onderskeid nie. In die praktyk kan'n evolusieteorie, in plaas van 'n teoretiese groep dissiplines, ook reeds dui op 'n wêreldbeskoulike oortuiging van naturalisties-materialistiese aard, 'n vooringenome kyk op die werklikheid. Die voorveronderstelling daarvan is dat alle aardse lewensvorme volledig verklaar kan word as toevallige uitkomste van blinde natuurkragte, as modifikasies van materie en dat die raaisel van lewe só opgelos is.

In die praktyk loop teorie en ideologie dus dikwels van twee kante in mekaar oor. Denkers se wetenskaplike redenasies is deurspek met ideologiese verwagtinge. Of, omgekeerd, kruie hul hulle ideologiese verwagtinge met wetenskaplike argumentasie.

Gewone leke wat hulle in een van die twee verwagtinge tuis vind - in plaas daarvan om krities te onderskei - sluk gou die hele storie (Klapwijk, 2009:53. Vergelyk ook Van den Beukel, 1990, 1994 en veral 2005 vir talle voorbeelde hiervan).

\section{6. 'n BIOLOOG LEES DIE BYBEL}

Hierbo (onder 2.1) is reeds die aandag daarop gevestig dat die hedendaagse biologiese wêreldbeeld vir Lever nie net die Skrif moet aanvul nie, maar ook moet verbeter - en myns insiens uiteindelik ondermyn. Dit het, soos hierbo ook reeds gesuggereer, waarskynlik geleidelik gebeur. Dit word egter besonder duidelik as'n mens sy heel vroegste werke, soos Lever (1956), met sy heel laaste werk kort voor sy dood (Lever, 2010) met mekaar vergelyk.

\subsection{Aanvanklike Standpunt}

In eersgenoemde werk (1956:68) skryf hy byvoorbeeld nog dat die Christenwetenskaplike op die problematiek van die ontstaan van die mens die volle lig van die Bybel moet laat val. Hy verwerp ook nog nie eksplisiet die sondeval (menslike degenerasie) ten gunste van kontinue progressie of evolvering nie en lê ook nog groot klem op die wesentlike verskil tussen dier en mens (vgl. ook Lever, 1948-1950).

Nogtans is toe reeds die kiem van die later duideliker spanning tussen Skrifgeloof en evolusieteorie sigbaar wanneer hy van mening is dat tussen geloofsvrae en wetenskaplike probleme skerp onderskei moet word (Lever, 1956:69).

Ook in Lever (1959:166 e.v.) word nog erken dat God in sy Skrifopenbaring nie antwoorde bied op dinge wat ons self kan ondersoek nie, maar antwoorde verskaf op dit wat buite ons ondersoekvelde lê. Onder laasgenoemde noem hy onder andere die begin van alles, die oorsprong van die kwaad, die oorwinning daarvan in Jesus Christus, die sin van die lewe en die voleinding van die wêreld.
Net meer as ' $\mathrm{n}$ dekade later word die verskuwing in Lever se denke egter al duidelik. In Lever (1973:65-75) lees ons alreeds dat die veroudering van die mens, net soos allerlei siektes, iets natuurliks, selfs noodsaaklik is.

Lever (1996) gaan nog verder. Die paradysverhaal is net 'n "model". Die oorspronklike staat van sondeloosheid word ontken, so ook die sondeval. Alles in die Genesis-1-3-verhaal openbaar slegs die "essensiële sin van die werklikheid. Wat die sin sou inhou, word nie gesê nie.

Lever (2010) gaan in hierdie trant voort. Die sondeval is slegs 'n grootse metafoor oor die essensie van die wêreldgebeure, want alle mense en volke is van die begin af deur die kwaad aangetas (p. 39). Die Bybelse wêreldbeeld moet dus deur die huidige (biologiese) wêreldbeeld vervang word. Eersgenoemde stel ons nogtans "op'n kleurryke wyse" voor die fundamentele vrae oor die oorsprong van die wêreld en die kwaad (p. 62).

Of Lever aan die einde van sy lewe nog enige betekenis aan God se Woord heg, sal nou vasgestel word deur in meer detail sy laaste werk te bekyk.

\subsection{Lever se aanspraak}

In die Voorwoord tot Lever (2010) maak die skrywer daarop aanspraak dat hy, as gereformeerde Christen, daarin sou geslaag het om die Bybel te lees sonder dat 'n enkele natuurwetenskaplike feit of teorie daaronder gesneuwel het. Terselfdertyd het hy nog bly glo aan die belangrikste Bybelse waarhede. Hy sou dus 'n volmaakte sintese tussen Christelike geloof en die evolusionêre wetenskap bewerk het waardeur nie een van die partye skade sou ly nie.

Die vraag is egter of sy aanspraak geldig is. Om die vraag te kan beantwoord, moet vasgestel word hoe hy die Bybel gelees het en watter kardinale waarhede hy daarin gevind het. Die antwoord op beide vrae sal uit die vervolg duidelik word.

\subsection{Die Bybel 'n teksboek?}

Lever beklemtoon herhaaldelik - en tereg - dat die Bybel nie 'n soort hand- of teksboek vir die wetenskap kan wees nie. Die rede waarom hy dit doen, is egter' $n$ verkeerde: Omdat die Bybelse wêreldbeeld verouderd sou wees.

Volgens die reformatories-wysgerige tradisie is die Bybel om 'n ander rede nie 'n teksboek nie: Omdat die Woord van God ' $n$ geloofsboek is en nie ' $n$ addisionele informasiebron vir die biologiese, historiese, politieke en ander wetenskappe is nie. Dit is die geloofslig waarin al hierdie wetenskappe beoefen behoort te word. 'n Mens kyk dus nie in die lig van die Skrif vir wetenskaplike gegewens nie, maar by die lig van die Skrif bestudeer jy die hele werklikheid, soek jy na lewensbeskoulike koers - ook vir jou vakgebied.

Dit sal nou blyk hoe, volgens 'n foutiewe Skrifbeskouing, Lever die Bybel ook verkeerd gebruik het en dit selfs daartoe gelei het dat hy kardinale Bybelse waarhede ontken het. Hy gebruik verskillende woorde soos dat wat die Woord van God meedeel 
onhistories sou wees (bv. p. 41, 61), op blote beeldspraak of metafore sou neerkom (bv. p. 39, 66), allegorieë bied, vol teenstrydighede is (bv. tussen die vier Evangelies) en selfs versinsels, fiktiewe oorleweringe en legendes sou bevat.

\subsection{Paradys en sondeval ontken}

Volgens Lever (2010:27) was die Paradys 'n fiksie. So ook die sondeval. Die mens was vanaf die begin deur die kwaad aangetas. Allerlei afwykings, siektes, veroudering en die dood hoort potensieel reeds tot die Skepper se oorspronklike skeppingsorde (p. 227).

Die rede waarom die sondeval verwerp word en die gevolge daarvan as natuurlik verklaar word, is heelwaarskynlik omdat 'n evolusieteorie vooruitgang veronderstel en nie agteruitgang kan akkommodeer nie.

Hierna gaan Lever die hele Bybelse geskiedenis na en gee byvoorbeeld veertien redes waarom die sondvloedverhaal 'n onmoontlikheid was (p. 63-76), waarom Jona nie in die vis kon oorleef het nie en waarom God nie die manna en kwartels tydens Israel se woestynreis voorsien het nie - dit kan alles op 'n natuurlike wyse verklaar word (onthou dat God volgens Lever slegs die Skepper was).

\subsection{Jesus Christus net 'n besondere mens}

Indien die sondeval nie plaasgevind het nie, is die verlossing in Christus vanselfsprekend nie nodig nie. Christus was vir Lever slegs "die Seun van die mens",'n heel besondere, die enigste egte mens, iemand wat' $n$ unieke plek onder die mensdom ingeneem het (p. 219). Hy is nie (ook) God nie. Hy roep God slegs - net soos ons mense - as sy Vader aan. Hy kon nie in die woestyn deur die duiwel versoek gewees het nie (p. 185); kon nie uit'n maagd gebore geword het nie, maar was ook die kind van Josef.

Christus was wel besonder intelligent en het vir vergiffenis, versoening en genesing geleef (p. 224). Omdat hy die enigste egte mens was, moes hy vanselfsprekend ook menslike lyding ondergaan. Die vraag of Hy dalk ook vir ons verlossing moes ly, kom nie ter sprake nie. 'n Mens wonder waarom Lever homself nog'n Christen kan noem.

\subsection{Die opstanding geloën}

Omdat Lever die dood as iets natuurliks beskou en Jesus nie meer as 'n unieke mens was nie, kan Lever die Bybelse opstandingsgeloof ook afskryf. Die dogtertjie van Jaïrus en die seun van die weduwee van Nain was skyndood en in die geval van Lasarus (al vir dae dood) was sy opwekking eenvoudig onmoontlik (p. 227).

Selfs die feit dat Christus self uit die dood opgestaan het - die hart van die Evangelie - skryf Lever aan later toegevoegde oorleweringe toe (p. 332). Ook sy verskyning daarna, hemelvaart, sit aan die regterhand van God die Vader en die verwagting van sy wederkoms op die wolke weerspieël volgens hom (Lever) slegs die destydse, antieke maar vandag verouderde, onaanvaarbare, wêreldbeeld (p. 232).
Soos met'n ry domino's, val een na die ander belangrike Bybelse waarhede in Lever se lees daarvan om. Omdat die sondeval nie sou plaasgevind het nie en die dood as gevolg daarvan nie ingetree het nie, is verlossing in Christus nie nodig nie, is sy opstanding ' $\mathrm{n}$ droom en is die hoop op 'n vernieude skepping ook afgewys.

\subsection{Die Bybel is mensewerk}

Dit verbaas nie om aan die einde van Lever (2010:258) te lees dat die Bybel nie die Woord van God in menslike woorde is nie, maar slegs mensewerk.

Dit lê ook voor die hand dat hy van die Apostoliese Geloofsbelydenis alleen die begin oorhou, naamlik dat hy "glo in God, die Skepper van hemel en aarde". Die gedeelte oor Christus (dat hy byvoorbeeld neergedaal het na die hel en opgevaar het na die hemel) word weer as 'n oorblyfsel van 'n foutiewe, verouderde wêreldbeeld afgeskryf. Hoe is dit moontlik dat Lever homself nog'n Christen kon noem?

Heel moontlik beskou hy homself nog slegs as 'n teïs wat aan een of ander skepper vashou. Hy sluit dan ook sy boek af met 'n hoofstuk getitel "Het geloof in die schepper houdt stand" (p. 255 e.v.). Waarop grond hy hierdie geloof as die hele Bybel slegs die produk van menslike fiksie is? Die antwoord daarop is reeds in punt 4 hierbo gegee.

\subsection{Natuurbelewing as openbaring}

Die oorsprong van die heidene se geloof in allerlei gode wat die werklikheid tot stand sou gebring het, lê volgens Lever in hulle belewing van die wonderlike natuur (p. 256). Hierdie natuurbelewing vorm duisende jare later ook die bron van die Bybelse geloof in net een God. Die Israeliete maak hiermee 'n stap vooruit. (Hy haal aan uit Psalms 19, 42 en 104.)

Ook by homself is dit die geval - 'n natuurwetenskaplike hoef nie'n ateïs te wees nie. Soos reeds verduidelik (vgl. 4.2), vermy hy egter die slaggat van die tradisionele natuurlike teologie wat vanuit die rede die bestaan van 'n Skepper wou bewys. Sy natuurbelewing is nie van analities-wetenskaplike aard nie. Dit is 'n persoonlike, emosionele belewing. En dit lei slegs tot die vermoede dat daar wél of nié ' $\mathrm{n}$ skepper sou bestaan (p. 259-2670).

Dit is die finale, onseker konklusie waarop Lever se sintese tussen evolusieteorie en Bybelse geloof uitloop. Hy het selfs die gedeelte van God se Skrifopenbaring dat Hy die Skepper is nie eers meer nodig nie! Ons vroeëre gevolgtrekking word herbevestig: Lever se wetenskaplike geloof het sy Christelike geloof gekelder.

\subsection{Reaksies}

Dit is geen wonder dat Lever se idees vroeg al hewige kritiek in Nederland ontlok het nie. Bybelgelowige Christene het heftig gereageer alreeds toe Lever in 1969 'n aantal radiopraatjies voor die Nederlandse Christelijke Radio-Vereniging gelewer het. (Gepubliseer in Lever, 1969 en in Engels in 1970). 
Die Nederlandse Evangelische Omroep saai byvoorbeeld daarna verskillende programme teen die evolusieteorie uit (vgl. Van Delden, 1977). En as gevolg van sy standpunt loop Lever ook deur onder die kritiek van die Christelike publiek. (Byvoorbeeld anonieme kaartjies met ' $\mathrm{n}$ aap daarop en die woorde daarby "groet jou eie neef".) Grondiger, Christelikfilosofiese kritiek is egter nodig.

Omdat die debat (veral aan die soortbegrip, vgl. Lever, 1950) tussen Lever en die filosoof Dooyeweerd (vgl. Lever \& Dooyeweerd, 1948, 1949, 1950 asook later Dooyeweerd 1959 en Spier, 1958) as bekender veronderstel kan word, volg ons hier die reaksie van die minder bekende werk van 'n ander Christelike filosoof, K.J. Popmna (1903-1986). Hy reageer op Lever (1969 in Nederlands, in 1970 ook in Engels gepubliseer).

\section{POPMA SE KRITIEK OP LEVER SE BESKOUINGE}

Popma was destyds (1969) natuurlik nog nie bewus van die latere ontwikkelinge in Lever se denke soos hierbo beskrywe nie. Die latere verskuiwings van Lever sou egter nie Popma se kritiek versag het nie, maar eerder verskerp het.

\subsection{Hoofkritiek}

Popma se hoofkritiek word reeds in die titel van sy boek duidelik: Evolutie - waar blijven de voorvragen? Dit toon ooreenkomste met van die vrae wat ekself alreeds op die voorafgaande bladsye gestel het.

Volgens Popma stel Lever die belangrike vraag hoe hy sy Christelike geloof en evolusie kan verenig, maar hy vra nie vooraf wat hy doen, waarmee hy besig is nie (p. 15, 61, 69). Want as hy ook die wat-vraag sou stel, sou hy eers veel dieperliggende religieuse, lewensbeskoulike, vakfilosofiese en filosofiese vrae moes beantwoord het.' $n$ Evolusionêre biologiese teorie behels, volgens Popma, veel meer as'n suiwer biologiese vertrekpunt.

Popma is dus glad nie beïndruk deur'n uitspraak soos "Geen mens, wat met die huidige biologiese gegewens op hoogte is, kan nog enigsins daaraan twyfel dat die mens deur 'n evolusieproses voortgebring is nie". Het hierdie selfde geloof, so vra hy, dan nie ook bloot evolusionêr ontstaan nie?

\subsection{Tien punte van kritiek}

Oor watter voorvrae of voorveronderstellings was Lever, volgens Popma, onduidelik of het hy geïgnoreer? Hier word slegs tien genoem (ter wille van oorsigtelikheid word hulle sistematies georden).

\subsubsection{Skryf Lever as bioloog of as Christen?}

Popma stel na aanleiding van die subtitel van Lever (1969) se boek (Waar blijven we? Een bioloog over de wording van deze aardse werkelijkheid) die vraag of Lever daarin as bioloog of as Christen skryf.
Die antwoord op hierdie vraag lê waarskynlik daarin dat Lever van 'n onderskeid tussen die dat van God se bo-tydelike skeppingsdaad en die hoe van die tydelike evolusionêre wordingsproses of ontvouing van die skepping uitgaan (Popma, 25). Hy kan dus afwisselend óf as Christen óf as bioloog praat.

Maar impliseer dit nie (soos hierbo onder punt 2 genoem) 'n dualisme, 'n soort intellektuele skisofrenie nie?

Popma wys daarop hoe Lever se wetenskap inderdaad sy Christelike geloof beïnvloed het. Lever $(1969: 28,45,51)$ ontken byvoorbeeld die sondeval as ' $\mathrm{n}$ historiese feit. Popma vestig egter die aandag daarop dat die sondeval nie sonder ernstige implikasies deur 'n Christen - die Christenwetenskaplike ingesluit - verwerp kan word nie. Verder ook dat die sondeval nie net biologiese gevolge gehad het nie, maar'n diep religieuse aangeleentheid was.

\subsubsection{Is evolusie vir Lever net 'n (nog onbewese) hipotese of meer?}

Indien evolusie vir Lever slegs ' $\mathrm{n}$ hipotese is, dan moet hy sê presies wat hy daaronder verstaan omdat, behalwe dat daar verskillende soorte hipoteses bestaan, 'n hipotese 'n nog onbewese veronderstelling is wat geverifieer moet word. Die afstamming van die mens uit die diereryk is volgens Popma so 'n onbewese hipotese.

Omdat 'n hipotese' $n$ leemte moet vul, val dit dikwels op 'n mite terug. So'n mite is die Elkerlijk-figuur wie se lotgevalle volgens Lever in Genesis 1 tot 3 beskryf sou word en die historiese Adam en Eva sou vervang (Popma, p. 22).

\subsubsection{Wat beteken wêreldbeeld?}

Popma stel ook die uiters belangrike vraag (waarop breedvoerig ingegaan word in Van der Walt, 2016b), wat die verskil en verband tussen wêreldbeeld en wêreldbeskouing volgens Lever is (p. 6) en ook die vraag watter wêreldbeeld Lever self huldig (p. 42).

\subsubsection{Harde feite of interpretasies daarvan?}

Popma wil graag weet wat presies Lever onder "feite" of "gegewens" verstaan. Kan sowel die seleksie, beskrywing en interpretasie van die feite vir hom op'n neutrale wyse plaasvind? Hierop het die huidige skrywer (vgl. Van der Walt, 2016a) ook reeds in detail ingegaan, sodat die leser daarna verwys kan word. Ook volgens Popma bestaan daar nie so iets soos "naakte" feite nie;'n feit is onafskeidelik aan' $n$ waarde-oordeel verbonde.

Popma wil natuurlik ook weet waarom kardinale Bybelse heilsfeite soos sondeval en verlossing nie ook vir Lever aanvaarbaar is nie.

\subsubsection{Evolusie sonder biologisme?}

Popma se vraag is verder of Lever evolusie kan voorstaan sonder om te verval in biologisme wat die fisies-biologiese eenheid en kontinuïteit oor al die ryke van stof, plant, dier en 
mens veronderstel (p. 27-32). Volgens Popma lei dit tot'n geslote wêreldbeeld. Ook tot ' $\mathrm{n}$ reduksionistiese visie op die mens as 'n blote chemies-biologiese wese (p. 61).

\subsubsection{Is die implikasies van 'n verbiologiseerde mensbeskouing verreken?}

'n Biologies-gereduseerde mensvisie hou volgens Popma duidelike gevolge vir alle fasette van die menslike lewe in. Indien die mens slegs'n hoër ontwikkelde dier sou wees, behoort hy seker ook soos'n dier te lewe (vgl. vir die meer resente debat hieroor in Clayton \& Schloss, 2004).

\subsubsection{Ook religieuse kennis verbiologiseer?}

Popma is van mening dat Lever selfs die Christen se religieuse kennis verbiologiseer wanneer hy (Lever) sy biologiese kennis aanwend om die Skrif te verstaan (p. 57). Popma was toe nog nie eers bewus nie van Lever (2010), hierbo in detail bespreek. Lever keer die orde om. Nie die Skrif moet in die lig van die biologie beskou word nie, maar om biologie in die lig van die Skrif te bestudeer, is volgens Popma die regte vertrekpunt.

\subsubsection{Het die biologie openbaringswaarde?}

Volgens Popma gaan Lever se biologisme so ver dat dit vir hom openbaringswaarde sou hê (p. 65). Dat hierdie soort "openbaring" egter met dié van God in sy Woord bots, blyk duidelik wanneer Lever op grond van biologiese insigte byvoorbeeld die sondeval onder die tafel invee.

Openbaring en wetenskap moet, hoewel hulle deur die Christenwetenskaplike nooit geskei mag word nie, duidelik onderskei word. Eenvoudig gestel, sou gesê kon word dat God se openbaring in die Skrif onder andere vir die mens verklaar wat hy self nie kan weet of ken nie (so byvoorbeeld die oorsprong van hemel en aarde asook die uiteindelike bestemming van alles as dade van God). Menslike kenne is tot die bestaande werklikheid beperk. Indien die wetenskap voorgee om ook kennis oor die oorsprong en voleinding van alles te bied, is dit nie langer wetenskap nie, maar het dit in spekulasie ontaard.

\subsubsection{Beoefen Lever integrale Christelike wetenskap?}

Lever is bekend daarvoor dat hy dikwels sy wetenskaplike betoog onderbreek en half uit die bloute' $n$ religieuse belydenis lewer deur byvoorbeeld Psalm 8 te siteer. Doen hy dit uit pastorale oorwegings teenoor sy Christelike gehoor? Popma (p. 42, 63) is egter nie daardeur beïndruk nie. So 'n werkwyse dui volgens hom op ' $n$ aangeplakte, oppervlakkige en nie 'n integraal-Christelike wetenskapsbeoefening nie. Dit lyk na ' $n$ bietjie Bybelse versiersuiker oor andersins Bybelsonverantwoordbare biologisme.

Soos ekself hierbo reeds verduidelik het (vgl. 6.3), kyk egte Christelike wetenskap nie in die lig van die Skrif (bepaalde Skrifgedeeltes as addisionele informasie) nie, maar by die lig van die Skrif (as normatiewe riglyn).

\subsubsection{Eindig die evolusieteorie nie uiteindelik in evolusionisme nie?}

Popma stel ten slotte die vraag wat ekself hierbo ook reeds gevra het (vgl. punt 5), naamlik of Lever se biologiese evolusieteorie nie op die ou einde tog maar in evolusionisme, 'n biologistiese lewensvisie, oorgaan nie. Kan hy werklik evolusieteorie en evolusionisme uitmekaar hou? Popma twyfel of dit die geval is (p. 21).

Lever skipper tussen die twee. Soms staan hy slegs evolusie voor, terwyl hy dan weer neig tot evolusionisme wanneer hy die standpunt verdedig dat die mens uit die dier ontwikkel het 'n mening wat volgens Popma (p. 44) nie op suiwer biologiese gronde alleen houdbaar is nie.

\section{TER AFSLUITING EN VERVOLG}

Popma het dit baie duidelik gemaak dat ' $\mathrm{n}$ mens vooraf eers duidelikheid oor jou eie (Christelike) voorveronderstellings moet hê voordat jy jou sinvol in die debat oor evolusie/ evolusionisme begewe.'n Mens kan maklik van'n evolusieteorie in evolulsionisme verval indien jy nie belangrike en dieper religieuse, lewensbeskoulike en filosofiese voorvrae stel en duidelik beantwoord nie. Dit geld sowel jou eie (Christelike) vertrekpunt as die filosofiese uitgangspunt van die evolusieteorie en evolusionisme. So ' $\mathrm{n}$ benadering vereis 'n teties-kritiese metode.

\section{1 'n Tetiese instelling}

Om teties vooraf jou eie visie te formuleer, ook al is dit hoe voorlopig, beteken nie bevooroordeeldheid nie, maar eenvoudige eerlikheid. Want neutraliteit is'n onmoontlikheid, ook op wetenskaplike gebied. Jou noodsaaklike tetiese instelling makk dit eers moontlik om werklik krities te kan wees.

\section{2 'n Kritiese instelling}

Die belangrike voorvrae is egter nie beperk tot wat' $\mathrm{n}$ Christen self glo of volgens God se Woord behoort te glo nie. Hy of sy moet ook vasstel wat die voorveronderstellings van die evolusionistiese teorieë en filosofieë self is. Eers dan kan 'n mens werklik besluit of die twee standpunte (jou eie en dié van die evolusionis) verenigbaar is of nie.

\section{3 'n Uitweg}

Al beperk ' $\mathrm{n}$ mens jouself net tot die Nederlandse lektuur, verskyn daar nog steeds talle publikasies oor die evolusieteorie en evolusionisme. Beperk 'n mens jou verder tot die gereformeerde kring, kan binne slegs 'n jaar byvoorbeeld die werke van Driessen en Nienhuis (2010), Flipse en Harinck (2011), Kruyswijk (2011) en Kwakkel en Van Houwelingen (2011) genoem word.

Daar bestaan vandag talle sulke Christelike analises wêreldwyd, sommige van hulle uiters oppervlakkig en eensydig, en min van hulle handel oor die filosofiese grondslae van die evolusionisme. Geen Christendenker het egter verskillende vorme van 
evolusionisme so grondig gepeil soos die Christenfilosoof, D.H.Th. Vollenhoven (1892-1978) nie. Hy het daarin geslaag om volgens 'n duidelik teties-kritiese metode die diepere, meestal verborge ontiese en antropologiese grondslae van verskillende soorte evolusionismes te ontbloot (vgl. bv. Vollenhoven, 2011). Sonder sy waardevolle bydrae mag hierdie reeks nie afgesluit word nie. Dit verdien egter'n laaste, volledige artikel (vgl. Van der Walt, 2016c).

\section{MEDEDINGENDE BELANGE}

Die skrywer verklaar dat hy geen finansiële of persoonlike verbintenis het met enige party wat hom nadelig of voordelig kon beïnvloed in die skryf van hierdie artikel nie.

\section{BIBLIOGRAFIE}

Aalders, G.Ch. 1932. De goddelijke openbaring de eerste drie hoofstukken van Genesis. Kampen: Kok.

Christelijke Encyclopedie 2012. Lever, Jan. http://www.protestant.nu/ Encyclopedie/tabid/359/Page/Lever Datum van toegang: 20/04/2016.

Clayton, P. \& Schloss, J., eds. 2004. Evolution and ethics; human morality in biological and religious perspective. Grand Rapids, Michigan: Eerdmans.

Diemer, J.H. 1963 (herdruk). Natuur en wonder. Amsterdam: Buijten \& Schipperheijn.

Diemer, J.H. 1977. Nature and miracle. Toronto: Wedge Publishing Foundation.

Driessen, A. \& Nienhuis, G., reds. 2010. Evolutie: Wetenschappelijk model of seculier geloof? Kampen: Kok.

Flipse, A. \& Harinck, G., reds. 2011. Waar komen we vandaan? Anderhalve eeuw evolutiedebat in protestants-christelijk Nederland. Amsterdam: VU Dokumentatie Centrum.

Klapwijk, J. 2009. Heeft evolutie een doel? Over schepping en emergente evolutie. Kampen: Kok.

Kruyswijk, H.H. 2011. Baas in eigen Boek. Evolutie en Schrifgezag bij de Gereformeerde Kerke in Nederland (1881-1981). Hilversum: Verloren.

Kuyper, A. 1899. Evolutie. Rede op 20 October gehouden. Amsterdam: Höveker en Wormser.

Kwakkel, G. \& Van Houwelingen, P.H.R. 2011. In den beginne en verder. Groningen: De Vuurbaak.

Lever, J. \& Dooyeweerd, H. 1948; 1949; 1950. Rondom het biologisch soortbegrip. Philosophia Reformata, 13:119-138, 14:6-32, 15:1-23.

Lever, J. 1950. Het soortbegrip in de Levende Structuren. Amsterdam: Vrije Universiteit.

Lever, J. 1956. Die mens in de biologie. (In Bavinck, J.H., Diepenhorst, I.A., Lever, J., Lindeboom, G.A. en Zuidema, S.U. De mens in de wetenschap. Kampen: Kok. p. 54-80.)

Lever, J. 1957a. Creationisme. (In Grosheide, F.W. \& Van Itterzon, G.P., reds. Christelijke Encyclopedie. Deel 2. Kampen: Kok. p. 314-315.)

Lever, J. 1957b. Evolutie. (In Grosheide, F.W. \& Van Itterzon, G.P., reds. Christelijke Encyclopedie. Deel 2. Kampen: Kok. p. 685-687.)

Lever, J. 1957c. Evolutionisme. (In Grosheide, F.W. \& Van Itterzon, G.P., reds. Christelijke Encyclopedie. Deel 2. Kampen: Kok. p. 687-688.)
Lever, J. 1958a. Creatie en evolutie. Wageningen: Zomer \& Keunings.

Lever, J. 1958b. Creation and evolution. Grand Rapids, Michigan: Eerdmans.

Lever, J. 1959. Evolutieperspectief. (In Lever, 2006. Langs de misterieuze grenzen van het leven. Van Woudenberg, R., red. Kampen: Ten Have. p. 146-168.)

Lever, J. 1969. Waar blijven we? Een bioloog over de wording van deze aardse werkelijkheid. Kok: Kampen \& Wageningen: Zomer \& Keunings.

Lever, J. 1970. Where are we headed? Grand Rapids, Michigan: Eerdmans.

Lever, J. 1973. Geïntegreerde biologie. Utrecht: Oosthoek's Uitgeversmaatschappij.

Lever, J. 1985. Schepping en evolutie; een zwerftog door de literatuur. Kampen: Kok.

Lever, J. 2005 (oorspronklik 1996). Onaansienlijk, onvoorstelbaar, onzienlijk: natuurwetenschap en natuurbeleving. (In Dekker, C., Meester, R., Van Woudenberg, R., reds. Schitterend ongeluk of sporen van ontwerp? Over toeval of doelgerichtheid in de evolutie. Kampen: Ten Have. p. 65-78.)

Lever, J. 2006a. Langs de misterieuze grensen van het leven. (Red. R. van Woudenberg.) Kampen: Ten Have.

Lever, J. 2006b. Toeval en zin en route. (In Van Woudenberg, R., red. Lever, J. Langs de misterieuze grenzen van het leven. Kampen: Ten Have. p. 199-216.)

Lever, J. 2010. Een bioloog leest de Bijbel. Almere: Transrivalis.

Popma, K.J. 1969. Evolutie - waar blijven de voorvragen? Amsterdam: Buijten en Schipperhijn.

Spier, J.M. 1958. Over het creationisme van dr. J. Lever. Bezinning, 13(1):44-59.

Van Delden, J.A. red. 1977. Schepping of evolutie? Argumenten voor en tegen de evolutieleer. Goes: Oosterbaan \& Le Cointre.

Van den Beukel, A. 1990. De dingen hebben hun geheim; gedachten over natuurkunde, mens en God. Baarn: Ten Have.

Van den Beukel, A. 1994. Met andere ogen. Baarn: Ten Have.

Van den Beukel, A. 2005. Darwinisme: Wetenskap en/of ideologie? (In Dekker, C., Meester, R. \& Van Woudenberg, R., reds. Schitterend ongeluk of sporen van ontwerp? Kampen: Ten Have. p. 101-116.)

Van der Walt, B.J. 2016a. Impliseer 'n evolusieteorie ook evolusionisme? Die debat onder gereformeerde denkers. In die Skriflig (vir publikasie voorgelê)

Van der Walt, B.J. 2016b. Kontra of pro evolusie? Drie Christelike bioloë se besinning oor die ontstaan van die wêreld. Tydskrif vir Christelike Wetenskap, 52(3): (vir publikasie voorgelê)

Van der Walt, B.J. 2016c. Onderweg na 'n Christelik-filosofiese analise van die evolusionisme: die bydrae van 'n konsekwent probleem-historiese metode. Tydskrif vir Christelike Wetenskap, 52(4): vir publikasie voorgelê.

Vollenhoven, D.H.Th. 2011 (oorspronklik 1963). Evolutionisme: Karakteristieke van alle typen. (In Vollenhoven, D.H.Th. Gastcolleges: erfenis voor het heden. Reds. Bril, K.A. \& Nijhoff, R.A. Amstelveen: De Zaak Haes. p. 159-166.) 